\title{
The Use of Periwinkle Shell Aggregate Concrete in Two Layer Reinforced Concrete Beam
}

\author{
John A. TrustGod ${ }^{1}$, Overo E. Kenneth ${ }^{2}$, Osharikeni E. Rita $^{3}$ \\ ${ }^{1,2,3}$ Faculty of Engineering, Department of Civil Engineering, Niger Delta University, \\ Wilberforce Island Bayelsa State

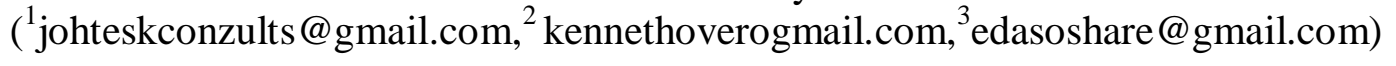

This article presents results of an experimental study involved testing of two-layer reinforced concrete beams with one-layer of periwinkle shell aggregates concrete both in tension and compression zone having cross-sections of $100 \times 150 \mathrm{~mm}$, the total span of $1200 \mathrm{~mm}$ and effective length $1100 \mathrm{~mm}$. Flexural reinforcement $\left(\mathrm{As}_{\mathrm{s}}=2 \Phi 8 \mathrm{~mm}\right)$ and $\left(\mathrm{A}_{\mathrm{S}}{ }^{1}=2 \Phi 8 \mathrm{~mm}\right)$ and shear reinforcement $(\mathrm{Asv}=\Phi 6 \mathrm{~mm} @ 200 \mathrm{~mm} \mathrm{c} / \mathrm{c})$. A total of twelve (12) reinforced beams were produced and grouped into; Type-RC (Beams and cubes cast completely of crushed stone aggregates concrete of 1:2:4 mix), Type-R1 (Crushed stone aggregates concrete (1:2:4 mix) with a depth of $75 \mathrm{~mm}$ at the top layer and Periwinkle aggregate concrete (1:2:1 mix) with a depth of $75 \mathrm{~mm}$ at the bottom layer, Type R2 (Periwinkle aggregates concrete (1:2:1 mix) with a depth of $75 \mathrm{~mm}$ at the top layer and $75 \mathrm{~mm}$ of crushed stone aggregate concrete (1:2:4 mix) at the bottom layer), Type R3 (Periwinkle aggregates concrete (1:2:1 mix) with a depth of $50 \mathrm{~mm}$ at the bottom layer and $100 \mathrm{~mm}$ of crushed stone aggregate concrete (1:2:4 mix) at the top layer. All the beam samples were tested under two-point loads. Results reveal that the two-layer beams had higher bending resistance as the control beams cast completely of crushed stone aggregate concrete. Also, the study showed that the beam Type-R1 had bending resistance of $6.62 \mathrm{kNm}$ and is $23.3 \%$ higher than beam Type-RC which had bending resistance of $5.08 \mathrm{kNm}$ while beam Type-R2 had bending resistance of $5.71 \mathrm{kNm}$ and is $11 \%$ higher than beam Type-RC. Beam Type-R3 had bending resistance of $6.21 \mathrm{kNm}$ and is $18.2 \%$ higher than beam Type-RC. The load-deflection records of all the beam samples were noted. The deflection of two-layer beams was considerably lower than control beams cast completely of crushed stone aggregates concrete. Base on the findings, it is recommended that periwinkle aggregate concrete can be used as a layer in reinforced concrete beams both in compression and tension zone, not more than $0.5 \mathrm{H}$.

Key words: Two-Layer, Periwinkle aggregate concrete, Bending Capacity, Mode of failure.

Corresponding Author: John Ayibatunimibofa TrustGod

\section{INTRODUCTION}

Increased infrastructural development worldwide has also increased the demand for more building materials. Concrete is a multipurpose material primarily used in construction sectors. Concrete is a composite construction material, made of cement, aggregates produced from a mixture of cement and water, sometimes enhancers are introduced to achieve desired properties of the concrete. Concrete is broadly used in almost all areas of human 
infrastructure. The volume of concrete used across the world is surpasses other building materials. Consequently, because of the unavailability and cost implication of these traditional building materials (such as granite, cement, etc.), the local demand for these building materials far exceeds the local supply as demanded, the local call for these construction materials far exceeds the local supply subsequent in an incessant rise in cost of building project in an undeveloped nation such as Nigeria. Thus, as the population increases every day, momentous determinations are required to avoid housing problems in the country, subsequently, more infrastructure needs to be provided at a lower cost. In Nigeria, the particle sizes larger than $4.75 \mathrm{~mm}$ (coarse aggregates), is very expensive, and these granular materials are transported to the construction sites hundreds of kilometers away the source, which is far beyond the cost of procuring the materials to make buildings in these areas. Under such conditions, there is a great demand for locally available agricultural left-over materials. Based on this point of view, the applicability of double layer reinforcement concrete rectangular beam with one-layer of periwinkle shell aggregate concrete in tension and compression will be investigated.

The term aggregate implies to the granular construction material, such as sand or blastfurnace slag and crushed stone. Aggregates form about $70 \%$ of the concrete product. To generally characterize between the particle sizes of the aggregate, the latter is categorized into two: coarse aggregate and fine aggregate. The particle sizes are related to the sieve number. The coarse aggregate (crushed stone) belongs to the particle sizes not passing through a No. 4 sieve. The fine aggregate (sand) belongs to the particle size not passing through a No. 200 sieve.

Periwinkle shell aggregates are the remnants after the comestible portion removed. Periwinkle is a sea molluscs with a spiral shell. The preparation method of periwinkle shell concrete is practically the same as the method of preparing conventional concrete, except that the periwinkle shell is used instead of crushed stone. Stated by Neville, (1981), marine dredging coarse aggregates may have a large shell content, which may have no unfavorable consequence on concrete strength, but if the shell content is large, it may decrease its workability. The periwinkle shell substance of particles sizes larger than $5 \mathrm{~mm}$ can be established by hand selection, using the correction of the method in BS 812 Part 2.

For lower concrete grade, plane round gravel is usually preferred, but for high bending strength, concrete made of angular crushed stone, it may be beneficial for all feasible concrete (Murdock, et al 1991). Thus, the roughness or smoothness of the aggregate surface stimulates the adhere between the aggregate and the cement paste in the hardened concrete.

Timothy et al, (2016) confirmed that 30\% replacement of crush stone with periwinkle shells aggregates and $30 \%$ replacement of sharp sand with periwinkle fine aggregate were (attain targeted compressive strength of $20 \mathrm{MPa}$ ) suitable. Also, it was measured to be $6.8 \%$ economical when $30 \%$ of periwinkle shells aggregates are mixed with $70 \%$ of crush stone as coarse aggregate.

Bamidele, (2002) researched on the effectiveness of periwinkle shells aggregates with different mix designs and also varying the proportion of periwinkles shells aggregates in the concrete ranging $0-100 \%$. Base on their results, the compressive strength at 28 days concrete produced at $100 \%$ periwinkle shells aggregates ranges from $11.77 \mathrm{MPa}$ to $15.65 \mathrm{MPa}$.

Ataria and.Wang, (2019) studied bending and shear performance of double layer reinforced concrete beam with various coarse aggregates. The top layer was constructed with crushed stone aggregate concrete of depth $\left(1 / 3^{\text {rd }}\right)$, while the tension $\left(2 / 3^{\text {rd }}\right)$ layer, using rubber recycled aggregate concrete. The results revealed that the double-layer beam achieves similar bending capacity as the control reinforced concrete beam produced completely of the crush stone aggregate concrete. For study samples without links, the double layer beam 
reached lower shear strength than the control beam. The lower shear strength was due to unzipping effect.

Iskhakov et al (2012) investigated two-layer beams, made up of steel fibered high strength concrete in the part that tends to be shorter (compression zone) and normal strength concrete in the part that tends to be longer (tensile zone), are researched experimentally. Three samples with the same fibre proportion, meeting the requirements of the suitable ductility level, were constructed and subjected to two-points loading. The results confirmed the function of fibres in a high concrete strength layer and develop a guide for two-layer beams design provisions.

Dahunsi (2003) revealed that periwinkle aggregate shells can be utilized as a partial substitute for granite in conventional building work and that the strength achieved in periwinkle-granite concrete is similar to that of classical granite concrete. Gravel obtain from the river is also a conventional building material used broadly with or without crushed stone. It is generally more economical than granite, but it is round and smooth in appearance.

The intention of this research is to find out the structural implication of two-layer reinforced concrete beams with one-layer of periwinkle shell aggregates concrete both in tension and compression zone respectively.

\section{MATERIALS AND METHODS}

\section{Materials}

Cement: Portland Limestone Cement of Grade 42.5 was used in the study. It conformed to B.S. EN 196-0; 2016.

Fine Aggregate: The fine aggregate utilized was obtained from river sand at Wilberforce Island, Bayelsa State, Nigeria. it confirmed to B.S. 882; 1992.

Coarse Aggregate: Crushed stones with rough-surfaces was used as coarse aggregate, obtained from Yenagoa, Bayelsa State, Nigeria. The maximum particle size was $12 \mathrm{~mm}$. It conformed to B.S. 882; 1992.

Periwinkle shells Aggregate

Periwinkle shells aggregates where obtained in Amassoma Town, Bayelsa state. The periwinkle shells used in this research were the remnants after the comestible portion removed. They were properly washed to remove crusts. It conformed to B.S. 882; 1992

Water: Portable water used was obtained in the Civil Engineering Laboratory building at the Niger Delta University. It conformed to BS 3148; 1980.

Formwork: Marine ply Board was utilized for the construction of the beam formworks. It conformed to BS 1881: Part 109, (1983)

Internal Reinforcement: Deformed bars were used as internal reinforcement both in bending and shear. It conformed to EN 1992-1-1:2004

\section{Method}

\section{Beam Samples}

According to EN 1992-1-1:2004, all the beam samples were reinforced with two 8mm diameter deformed bars both in the part that tends to be longer (tension zone) and part tends to be short (compression zone). $6 \mathrm{~mm}$ diameter deformed bars placed at $200 \mathrm{~mm}$ apart were used as shear reinforcement. Total of twelve beams cross-section of $100 \times 150 \mathrm{~mm}$, overall length of $1200 \mathrm{~mm}$ and effective span of $1100 \mathrm{~mm}$ were constructed. Three beams out of twelve were used as control beams produced completely of crushed stone aggregate concrete of 1:2:4 mix ratio. Then, seven of which were produced in two-layers as stated below: 

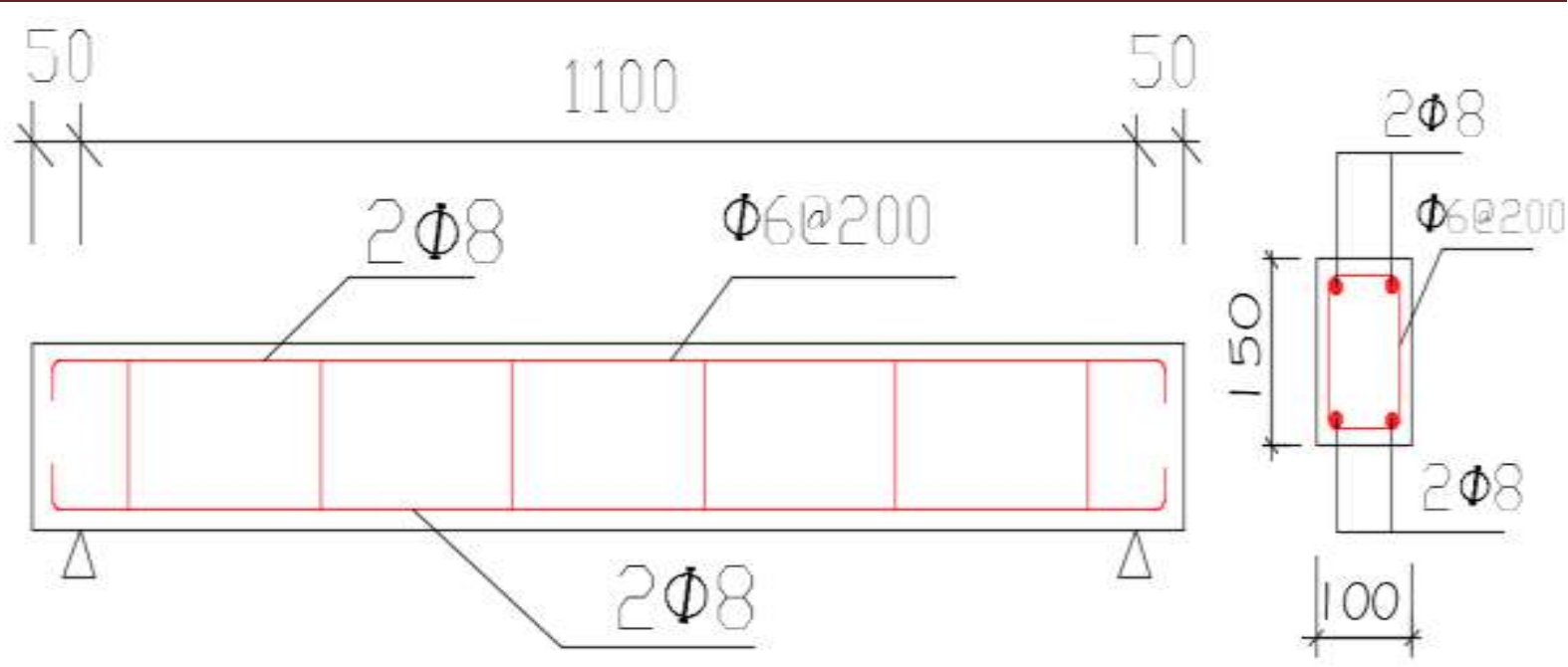

Fig.1: Details of Flexural and Shear Deformed Bars and Dimensions (mm)

Type-RC: Beams and cubes cast completely of crushed stone aggregates concrete of 1:2:4 mix (Control).

Type R1: Crushed stone aggregates concrete (1:2:4 mix) with a depth of $75 \mathrm{~mm}$ at the top layer and Periwinkle aggregate concrete (1:2:1 mix) with a depth of $75 \mathrm{~mm}$ at the bottom layer.

Type R2: Periwinkle aggregates concrete (1:2:1 mix) with a depth of $75 \mathrm{~mm}$ at the top layer and $75 \mathrm{~mm}$ of crushed stone aggregate concrete $(1: 2: 4 \mathrm{mix})$ at the bottom layer

Type R3: Periwinkle aggregates concrete $(1: 2: 1 \mathrm{mix})$ with a depth of $50 \mathrm{~mm}$ at the bottom layer and $100 \mathrm{~mm}$ of crushed stone aggregate concrete (1:2:4 mix) at the top layer. All the beam samples were tested under two-point loads.

Type-RP: Cubes cast completely of Periwinkle aggregates concrete of 1:2:1 mix.

\section{Cubes Samples}

Fifteen standard concrete cubes $(150 \times 150 \times 150 \mathrm{~mm})$ were made for each set of beam-types to obtain 28 days compressive strength of concrete, with a mix ratio of 1:2:4 for the crushed stone aggregate concrete (control) cubes and a mix ratio of 1:2:1 for the periwinkle aggregate concrete cubes. The cube specimens were cured and were secured against dryness. Concrete cube samples were tested to failure at 28 days.

\section{RESULTS AND DISCUSSION}

\section{Results}

Research results of a two-layer reinforced concrete beam with one-layer of periwinkle shell aggregate concrete both in tension and compression zone are presented in tables and figures. Table 1 shows the direct observation of test results and failures modes of a two-layer reinforced concrete beam. Table 5 showed a compressive strength of concrete specimen's types RC, R1, R2, R3 and RP. Table 2,3 and 4 presents the calculated results of bending capacity, cracking capacity and tensile stress of test beams. 
DOI : https://dx.doi.org/10.26808/rs.aj.i9v1.01

American Journal of Sustainable Cities and Society

Issue 9, Vol. 1 January- December 2020

Available online on http://www.rspublication.com/ajscs/ajsas.html

ISSN $2319-7277$

Table 1: Experimental results of tested two-layer beams

\begin{tabular}{|c|l|c|c|c|l|}
\hline $\begin{array}{l}\text { Sample } \\
\text { Type }\end{array}$ & $\begin{array}{l}\text { Number of } \\
\text { samples }\end{array}$ & $\begin{array}{l}\text { First Crack } \\
\text { Load }(\mathrm{kN})\end{array}$ & $\begin{array}{l}\text { Failure Load } \\
(\mathrm{kN})\end{array}$ & $\begin{array}{l}\text { Deflection at } \\
\text { Failure (mm) }\end{array}$ & Mode of Failure \\
\hline \multirow{3}{*}{ Type-RC } & Sample 1 & 21.98 & 27.48 & 7.50 & Flexural/Shear/Crushing \\
& Sample 2 & 17.59 & 27.84 & 3.99 & Flexural/Shear/Crushing \\
& Sample 3 & 18.32 & 27.84 & 4.65 & Flexural/Shear/Crushing \\
\hline \multirow{3}{*}{ Type-R1 } & Sample 1 & 25.65 & 37.37 & 6.00 & Flexural/Crushing \\
& Sample 2 & 29.31 & 34.80 & 5.70 & Flexural/Shear/Crushing \\
& Sample 3 & 27.48 & 36.09 & 5.85 & Flexural/Crushing \\
\hline \multirow{3}{*}{ Type-R2 } & Sample 1 & 25.65 & 31.14 & 5.81 & Flexural/Shear/Crushing \\
& Sample 2 & 29.31 & 31.14 & 6.20 & Flexural/Shear/Crushing \\
& Sample 3 & 27.48 & 31.14 & 6.01 & Flexural/Shear/Crushing \\
\hline & Sample 1 & 29.31 & 32.97 & 5.61 & Flexural/Shear/Crushing \\
& Sample 2 & 25.65 & 34.80 & 6.30 & Flexural/Shear/Crushing \\
& Sample 3 & 27.48 & 33.89 & 5.96 & Flexural/Shear/Crushing \\
\hline
\end{tabular}

Table 2: Bending Capacity of Beams

\begin{tabular}{|c|c|c|c|}
\hline $\begin{array}{c}\text { Specimen } \\
\text { Type }\end{array}$ & $\begin{array}{c}\text { Number of } \\
\text { Samples }\end{array}$ & $\begin{array}{c}\text { Failure Load } \\
(\mathrm{kN})\end{array}$ & $\begin{array}{c}\text { Bending Capacity } \\
(\mathrm{kNm})\end{array}$ \\
\hline \multirow{3}{*}{ Type-RC } & Sample 1 & 27.48 & 5.04 \\
& Sample 2 & 27.84 & 5.10 \\
& Sample 3 & 27.84 & 5.10 \\
\hline \multirow{3}{*}{ Type-R1 } & Sample 1 & 37.37 & 6.85 \\
& Sample 2 & 34.80 & 6.38 \\
& Sample 3 & 36.09 & 6.62 \\
\hline \multirow{2}{*}{ Type-R2 } & Sample 1 & 31.14 & 5.71 \\
& Sample 2 & 31.14 & 5.71 \\
& Sample 3 & 31.14 & 5.71 \\
\hline \multirow{2}{*}{ Type-R3 } & Sample 1 & 32.97 & 6.04 \\
& Sample 2 & 34.80 & 6.38 \\
& Sample 3 & 33.89 & 6.21 \\
\hline
\end{tabular}

Table 3: Cracking Capacity of Beams

\begin{tabular}{|c|c|c|c|}
\hline $\begin{array}{c}\text { Specimen } \\
\text { Type }\end{array}$ & $\begin{array}{c}\text { Number of } \\
\text { Samples }\end{array}$ & $\begin{array}{c}\text { First Crack Load } \\
(\mathrm{kN})\end{array}$ & $\begin{array}{c}\text { Cracking Capacity } \\
(\mathrm{kNm})\end{array}$ \\
\hline \multirow{3}{*}{ Type-RC } & Sample 1 & 21.98 & 4.03 \\
& Sample 2 & 17.59 & 3.22 \\
& Sample 3 & 18.32 & 3.36 \\
\hline \multirow{3}{*}{ Type-R1 } & Sample 1 & 25.65 & 4.70 \\
& Sample 2 & 29.31 & 5.37 \\
& Sample 3 & 27.48 & 5.04 \\
\hline \multirow{2}{*}{ Type-R2 } & Sample 1 & 25.65 & 4.70 \\
& Sample 2 & 29.31 & 5.37 \\
& Sample 3 & 27.48 & 5.04 \\
\hline \multirow{2}{*}{ Type-R3 } & Sample 1 & 29.31 & 5.37 \\
& Sample 2 & 25.65 & 4.70 \\
& Sample 3 & 27.48 & 5.04 \\
\hline
\end{tabular}


DOI : https://dx.doi.org/10.26808/rs.aj.i9v1.01

American Journal of Sustainable Cities and Society

Issue 9, Vol. 1 January- December 2020

Available online on http://www.rspublication.com/ajscs/ajsas.html

ISSN $2319-7277$

Table 4: Tensile Stress of Beams

\begin{tabular}{|c|c|c|c|}
\hline $\begin{array}{c}\text { Specimen } \\
\text { Type }\end{array}$ & $\begin{array}{c}\text { Number of } \\
\text { Samples }\end{array}$ & $\begin{array}{c}\text { First Crack Load } \\
(\mathrm{kN})\end{array}$ & $\begin{array}{c}\text { Tensile Stress } \\
(\mathrm{MPa})\end{array}$ \\
\hline \multirow{3}{*}{ Type-RC } & Sample 1 & 21.98 & 10.75 \\
& Sample 2 & 17.59 & 8.60 \\
& Sample 3 & 18.32 & 8.96 \\
\hline \multirow{3}{*}{ Type-R1 } & Sample 1 & 25.65 & 12.54 \\
& Sample 2 & 29.31 & 14.33 \\
& Sample 3 & 27.48 & 13.43 \\
\hline \multirow{3}{*}{ Type-R2 } & Sample 1 & 25.65 & 12.54 \\
& Sample 2 & 29.31 & 14.33 \\
& Sample 3 & 27.48 & 13.43 \\
\hline \multirow{2}{*}{ Type-R3 } & Sample 1 & 29.31 & 14.33 \\
& Sample 2 & 25.65 & 12.54 \\
& Sample 3 & 27.48 & 13.43 \\
\hline
\end{tabular}

Table 5: 28-Days Compressive Strength

\begin{tabular}{|c|c|c|c|c|}
\hline $\begin{array}{c}\text { Specimen } \\
\text { Type }\end{array}$ & $\begin{array}{c}\text { Size of Cube } \\
(\mathrm{mm})\end{array}$ & $\begin{array}{c}\text { Weight of } \\
\text { Specimen }(\mathrm{kg})\end{array}$ & $\begin{array}{c}\text { Applied } \\
\text { Compressive } \\
\text { Load }(\mathrm{kN})\end{array}$ & $\begin{array}{c}\text { 28-Day Compressive } \\
\text { Strength }(\mathrm{MPa})\end{array}$ \\
\hline Type-RC & $150 \times 150 \times 150$ & 8 & 643.3 & 28.60 \\
\hline Type-R1 & $150 \times 150 \times 150$ & 8.5 & 385.5 & 17.13 \\
\hline Type-R2 & $150 \times 150 \times 150$ & 8.2 & 375 & 18.67 \\
\hline Type-R3 & $150 \times 150 \times 150$ & 8 & 425 & 9.18 \\
\hline Type-RP & $150 \times 150 \times 150$ & 6.2 & 206.6 & \\
\hline
\end{tabular}

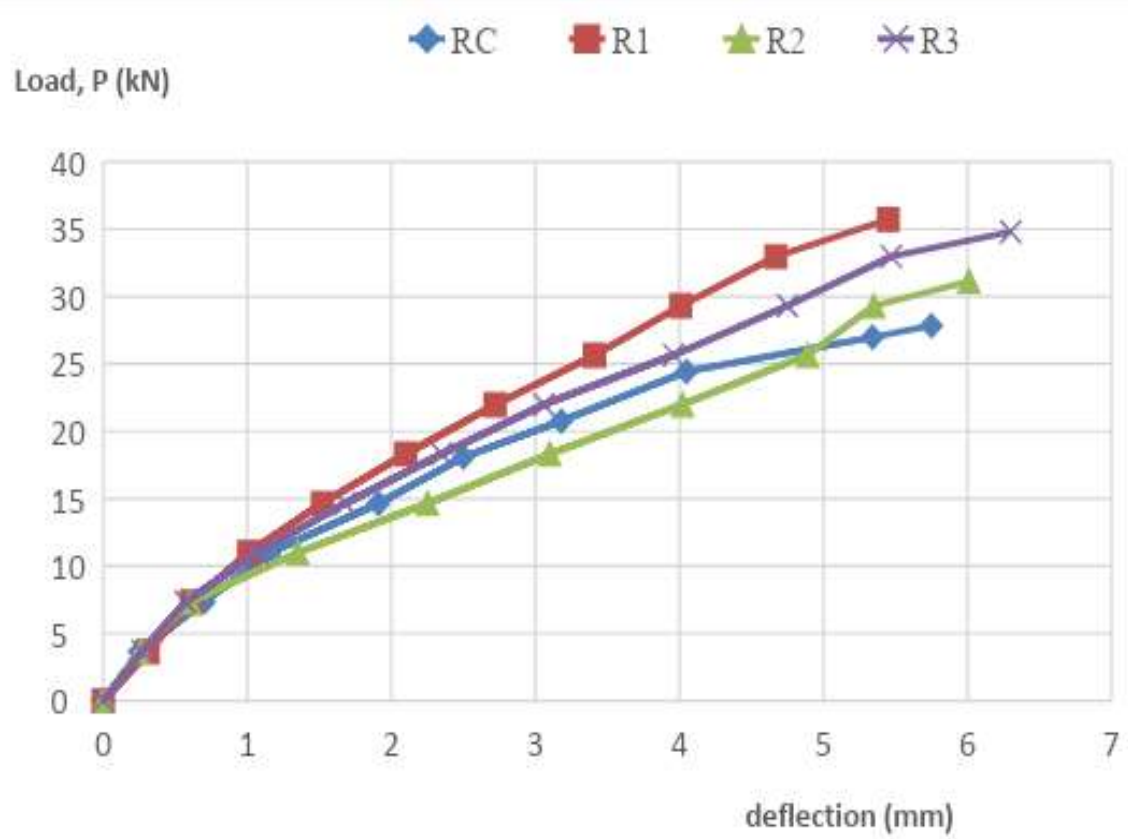

Fig. 2. Load against deflection curve of experimental results of beam Type-RP, R1, R2, R3 


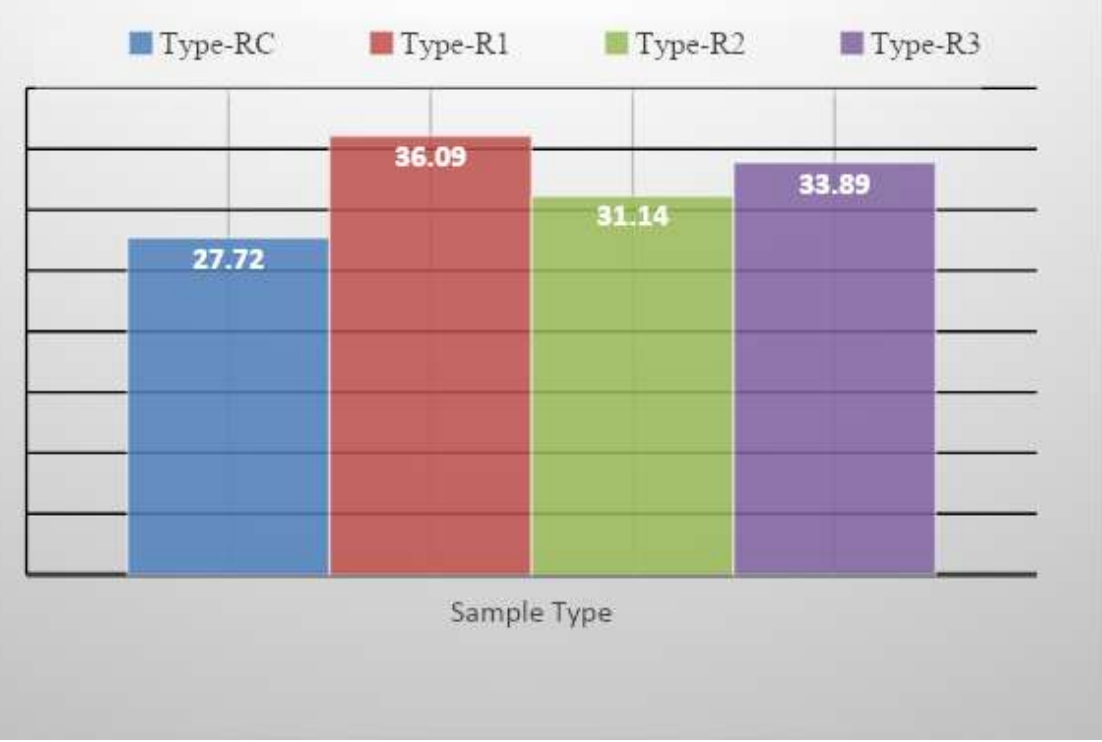

Fig. 3 Failure load of the sample Types

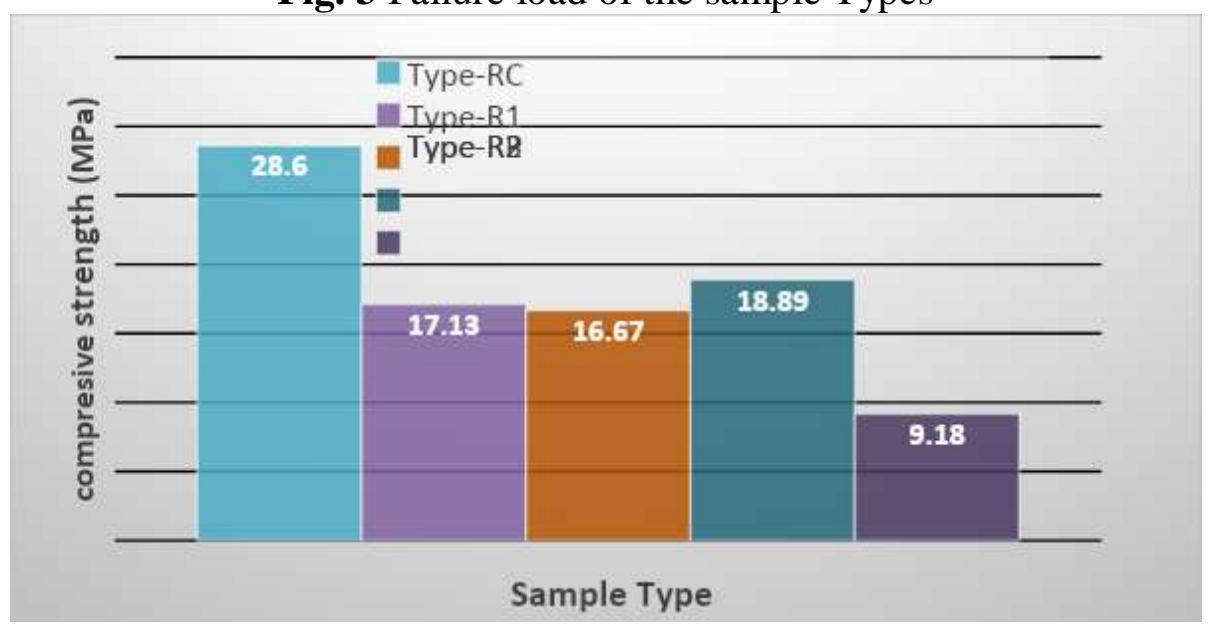

Fig. 4. Graph Showing compressive strength at 28-day for Cube Type-RC, R1, R2, R3 and $\mathrm{RP}$

\section{Discussion}

This section illustrates the study results of the various tests carried out on two-layer reinforced concrete beam with one-layer of periwinkle shell aggregates concrete both in tension and compression face.

\section{Ultimate Load-Carrying Capacity}

From Table 1, it was noted that the control beams cast completely of crushed stone aggregate concrete of 1:2:4 mix ratio had less load carrying capacity compared to that of the two-layer reinforced concrete beam with one-layer of periwinkle shell aggregates concrete both in tension and compression face. Deflection performance and the load-carrying capacity of the study sample beams were observed.

\section{Load at Early Crack}

Two-point static loading was performed on all the two-layer beams and at each load increment, deflection and crack patterns were observed. The first crack load of all the beams was recorded and is given in Table 1 . The beam Type-RC, developed an initial crack at $19.29 \mathrm{kN}$ and cracking capacity of $3.34 \mathrm{kN}$, while the beam Type-R1, Type-R2 and Type-R3 
developed an initial crack at $27.48 \mathrm{kN}$ and $5.04 \mathrm{kN}$ respectively. It was observed that all the two-layer reinforced concrete beam with one-layer of periwinkle shell aggregates concrete both in tension and compression face had higher load carrying and cracking capacity compared to the control beams cast completely of crushed stone aggregate concrete.

\section{Bending capacity}

From Table 2, it is confirmed that the two-layer beams had higher bending resistance as the control beams cast completely of crushed stone aggregate concrete. Also, the study showed that the beam Type-R1 had bending resistance of $6.62 \mathrm{kNm}$ and is $23.3 \%$ higher than beam Type-RC which had bending resistance of $5.08 \mathrm{kNm}$ while beam Type-R2 had bending resistance of $5.71 \mathrm{kNm}$ and is $11 \%$ higher than beam Type-RC. Beam Type-R3 had bending resistance of $6.21 \mathrm{kNm}$ and is $18.2 \%$ higher than beam Type-RC.

\section{Load Deflection Performance}

The load-deflection records of all the beam samples was observed. The deflection of each two-layer beam was compared with that of the beams cast completely of crushed stone aggregates concrete of 1:2:4 mix. Similarly, the load-deflection performance was compared between two-layer beams. From figure 2, the deflections were considerably lower than control beams cast completely of crushed stone aggregates concrete. The beam Type-RC (control beam) failed at $27.72 \mathrm{kN}$ load, measured deflection at $27.72 \mathrm{kN}$ load of $5.38 \mathrm{~mm}$. The beam Type-R1 at $27.72 \mathrm{kN}$ load, it deflects $3.73 \mathrm{~mm}$, which is $31 \%$ less than the beam Type$\mathrm{RC}$ (control beam). The beam Type-R2 at $27.72 \mathrm{kN}$ load, it deflects $5.10 \mathrm{~mm}$, which is $5 \%$ less than the beam Type-RC (control beam). The beam Type-R3 at $27.72 \mathrm{kN}$ load, it deflects $4.18 \mathrm{~mm}$, which is $22 \%$ less than the beam Type-RC (control beam).

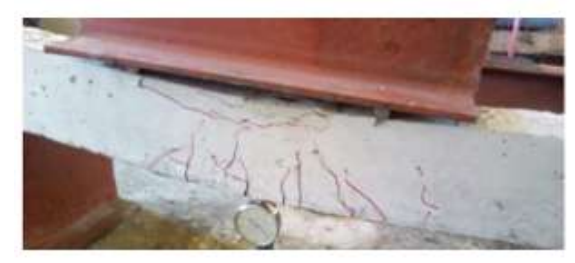

(a)

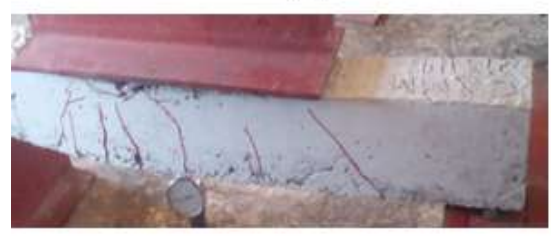

(c)

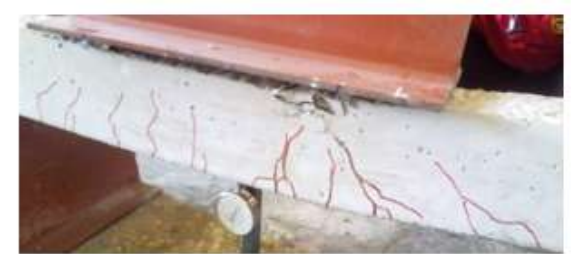

(b)

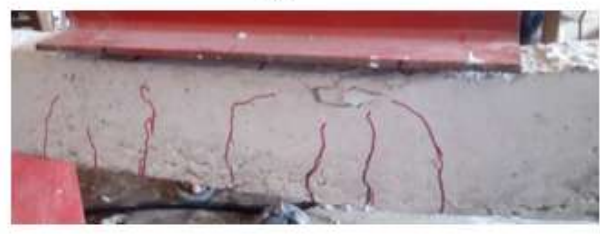

(d)

Fig. 5. Mode of Failure of test specimen: (a) Type-RC, (b) Type-R1, (c) Type-R2, and (d) Type-R3

\section{Compressive Strengths}

The concrete compressive strengths results of a two-layer reinforced concrete beam with onelayer of periwinkle shell aggregates concrete both in tension and compression face and concrete compressive strengths results of cubes samples cast completely of Periwinkle aggregates concrete of 1:2:1 mix and cubes formed completely of crushed stone aggregate concrete of 1:2:4 mix at 28-days are shown in Table 5. It is noted that the cube type-RC (control cube sample) had a compressive strength of 28.60MPa. From figure 4, the cube type$\mathrm{R} 1$ had a compressive strength of $17.13 \mathrm{MPa}$. The cube type-R2 had compressive strength of 
16. 67MPa. The cube type-R3 had a compressive strength of $18.89 \mathrm{MPa}$. The cube type-RP had a compressive strength of $9.18 \mathrm{MPa}$. The results revealed that the control beams cast completely of crushed stone aggregate concrete had higher compressive strength compared to that of the two-layer reinforced concrete beam with one-layer of periwinkle shell aggregates concrete both in tension and compression face, Also, The cube-type R1 had higher compressive strength than the cube-type RP.

\section{CONCLUSION}

Investigations have been carried out to study the effectiveness of two-layer reinforced concrete beams of one-layer of periwinkle shell aggregates concrete both in tension and compression zone. From the research results, the following conclusions can be drawn.

i. Use of two-layer reinforced concrete beam with one-layer of periwinkle shell aggregates concrete both in tension and compression face shows considerable improvement in ultimate load carrying capacity.

ii. Using two-layer reinforced concrete beam with one-layer of periwinkle shell aggregates concrete both in tension and compression face restrains the central deflection.

iii. Two-layer reinforced concrete beam with one-layer of periwinkle shell aggregates concrete both in tension and compression face leads to rise the ductility and toughness of the beam.

iv. Crushed stone aggregate concrete layer of depth $0.5 \mathrm{x}$ the depth of the beam at the top and Periwinkle concrete with a depth of $0.5 \mathrm{x}$ the depth of the beam at the bottom is $23.2 \%$ higher than beams formed completely of crushed stone aggregates concrete.

v. Periwinkle aggregate concrete with a depth of $0.5 x$ the depth of the beam at the top layer and $0.5 \mathrm{x}$ the depth of the beam of crushed stone aggregate concrete at the bottom layer is $11 \%$ higher than the beams formed completely of crushed stone aggregates concrete.

vi. Periwinkle aggregate concrete with a depth of $\frac{1}{3} \mathrm{x}$ the depth of the beam at the bottom layer and $\frac{2}{3} \mathrm{x}$ the depth of the beam of crushed stone aggregate concrete at the top layer is $18.21 \%$ higher than the beams formed completely of crushed stone aggregates concrete.

\section{REFERENCE}

I B.S. 882; 1992.Specification for Aggregates from natural sources for concrete. British Standards Institute. London, United Kingdom.

II B.S. EN 196-0; 2016. Method of Testing Cement. Determination of fineness. British Standards Institute. London, United Kingdom

III Bamidele, I.O.D. (2002): "Properties of Periwinkle Granite Concrete. Journal of civil engineering Vol. 8: Pg. 27-36.

IV $\quad$ BS 1881: Part 109, (1983); Method for making test beams from fresh concrete.

V BS 3148; 1980. Methods of test for water for making concrete. British Standards Institute. London, United Kingdom concrete in tension.

VI Dahunsi, B. I. 2003. Properties of Periwinkle-Granite Concrete: Journal of Civil Engineering, JKUAT. 8(1). 27-35.

VII EN 1992-1-1:2004. Design of concrete structures, general rules and rules for buildings 
VIII Iskhakov, Y. Ribakov ,K.Holschemacher and T. Mueller (2012) Experimental Investigation of Full Scale Two-Layer Reinforced Concrete Beams. Journal ,Volume 21,- Issue 4, Pages 273-283

IX Murdock L.J., Brook K.M., Dewar J.D., (1991), Concrete Materials and Practice. Edward Arnold London.

X Neville A. M. (1981); Properties of Concrete, 3rd edition, Pitman publishing Limited London, pp, 154.

XI R.B. Ataria and Y.C. Wang (2019) Bending and shear behaviour of two layer beams with one layer of rubber recycled aggregate. Elsevier, ScienceDirect, Volume 20, page 214-225

XII Timothy Soneye, Anthony Nkem Ede, Gideon Olukunle Bamigboye and David Olatunde Olukanni (2016) The Study of Periwinkle Shells as Fine and Coarse Aggregate in Concrete Works. (CU-ICADI) International Conference on African Development Issues, Ota, Nigeria 